\title{
Simulation of Dish Stirling Solar Concentrator by Greenius Software
}

\author{
A. Kaddour* and B. Benyoucef \\ Unit of Research Materials \& Renewable Energies, University of Tlemcen, Algeria
}

\begin{abstract}
Solar energy is the source of the most promising energy and the powerful one among renewable energies. Photovoltaic electricity (statement) is obtained by direct transformation of the sunlight into electricity, by means of cells statement. Greenius is a powerful simulation environment for the calculation and analysis of renewable power projects such as solar thermal trough power plants, photovoltaic systems, wind parks or Dish/Stirling systems. This program offers a unique combination of detailed technical and economical calculations as they are needed for planning and installation of renewable power projects. Greenius is the first simulation environment with comfortable user interface for the analysis of solar thermal power plants, photovoltaic systems and wind parks. In fact, any heat energy source can be used with the Stirling engine. The solar radiation can be focused onto the displacer hot-end of the Stirling engine, thereby creating a solar-powered prime mover. The direct conversion of solar power into mechanical power reduces both the cost and complexity of the prime mover. In theory, the principal advantages of Stirling engines are their use of an external heat source and their high efficiency. Stirling engines are able to use solar energy that is a cheap source of energy. Since during two-thirds of the day, solar energy is not available, solar/fuel hybrids are needed [1].

Two versions of Greenius exist: the standard and the expert version. The expert version has extended input and calculation options for solar thermal trough power plants. In all other points both versions are identical. Greenius distinguishes itself by numerous export possibilities for intermediate and final results. Almost all contents of tables and graphics can be copied to other windows applications or can be saved in other formats. The calculation results are detailed and the extended simulations perform very fast. Greenius was developed the German Aerospace Centre (DLR). Dr. Rainer Kistner, Winfried Ortmanns, Dr. Volker Quaschning and Dr. Jürgen Dersch belonged to the development team. Marketing, distribution and service are made under licence of DLR [2].
\end{abstract}

Keywords: Dish concentrator; Simulation; Optimization; Greenius software; Stirling engine.

\section{Introduction}

A Stirling engine is a heat engine operating by cyclic compression and expansion of air or other gas, the working fluid, at different temperature levels such that there is a net conversion of heat energy to mechanical work. Like the steam engine, the Stirling engine is traditionally classified as an external combustion engine, as all heat transfers from the working fluid, combustion takes place through the engine wall. This contrasts with an internal combustion engine where heat input is by combustion of a fuel within the body of the working fluid. Unlike a steam engine's (or more generally a Rankine cycle engine's) usage of a working fluid in both its liquid and gaseous phases, the Stirling engine encloses a fixed quantity of permanently gaseous fluid such as air.

Typical of heat engines, the general cycle consists of compressing cool gas, heating the gas, expanding the hot gas, and finally cooling the gas before repeating the cycle. The efficiency of the process is narrowly restricted by the efficiency of the Carnot cycle, which depends on the temperature difference between the hot and cold reservoir.

Originally conceived in 1816 as an industrial prime mover to rival the steam engine, its practical use was largely confined to low-power domestic applications for over a century [3].

The Stirling engine is noted for its high efficiency compared to steam engines [4] quiet operation, and the ease with which it can use almost any heat source. This compatibility with alternative and renewable energy sources has become increasingly significant as the price of conventional fuels rises, and also in light of concerns such as peak oil and climate change. This engine is currently exciting interest as the core component of micro combined heat and power (CHP) units, in which it is more efficient and safer than a comparable steam engine $[5,6]$.

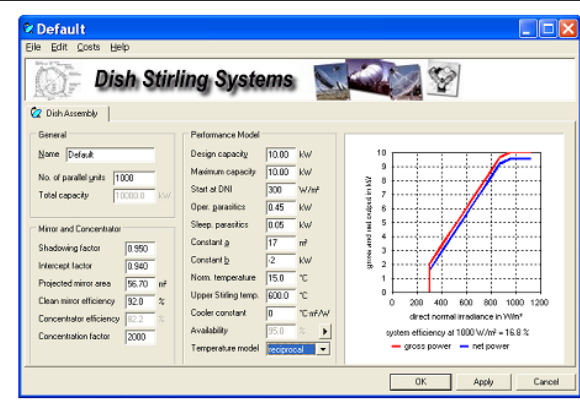

Figure 1: Parameters of Dish Stirling concentrator.

The technical parameters of a Dish/Stirling-System are defined here. The data for the mirror and concentrator are only informal with the area that is needed for the calculation of the efficiency. The characteristics for a Dish-system are calculated and shown in a graphic continuously $[7,8]$.

Sleeping parasitics means the electricity consumption during none operating hours (hours with DNI lower than start DNI). This electricity consumption might be used e.g. for tracking. (Figure 1)

*Corresponding author: A. Kaddour, Unit of Research Materials \& Renewable Energies, University of Tlemcen, B.P 119, 13000 Tlemcen, Algeria, Tel: +213553869972; Fax: +21343215889; E-mail: kaddour.majid@gmail.com

Received June 01, 2012; Accepted July 03, 2012; Published July 06, 2012

Citation: Kaddour A, Benyoucef B (2012) Simulation of Dish Stirling Solar Concentrator by Greenius Software. J Elec Electron 1:103. doi:10.4172/2167101X.1000103

Copyright: (c) 2012 Kaddour A, et al. This is an open-access article distributed under the terms of the Creative Commons Attribution License, which permits unrestricted use, distribution, and reproduction in any medium, provided the original author and source are credited. 


\section{Model equations}

Gross electrical performance [9]:

(1)

$$
P_{\text {gross }}=\left\{\begin{array}{l}
a \cdot E_{\text {cor }}+b \\
\text { Oelse }
\end{array} \text { If } \mathrm{E}_{\mathrm{DNI}} \geq \mathrm{E}_{\mathrm{DNI}, \min }\right.
$$

$\mathrm{E}_{\text {cor }}$ : corrected irradiance in $\mathrm{W} / \mathrm{m}^{2}$

$\mathrm{E}_{\mathrm{DNI}}$ : direct normal irradiance in $\mathrm{W} / \mathrm{m}^{2}$

$\mathrm{E}_{\mathrm{DNI}, \mathrm{min}}$ : minimal direct normal irradiance for starting generation in $\mathrm{W} / \mathrm{m}^{2}$

a: performance model constant in $\mathrm{W}_{\mathrm{e}} /\left(\mathrm{W} / \mathrm{m}^{2}\right)$

b: performance model constant in $\mathrm{W}_{\mathrm{e}}$

Corrected irradiance

$\mathrm{E}_{\text {cor }}=\mathrm{E}_{\mathrm{DNI}} \cdot \mathrm{f}_{\text {ref }} \cdot \mathrm{f}_{\text {tem }}$

$\mathrm{f}_{\text {tem }}$ : temperature correction factor

$\mathrm{f}_{\text {ref }}$ : reflection correction factor

Reflection correction factor:

$\mathrm{f}_{\text {ref }}=\mathrm{f}_{\text {shadowing }} \cdot \mathrm{f}_{\text {intercept }}$

$\mathrm{f}_{\text {shadowing }}$ : shadowing and blockage factor

$\mathrm{f}_{\text {shadowing }}$ : intercept factor

Temperature correction factor:

$f_{\text {temp }}=\left\{\begin{array}{l}\frac{\vartheta_{\text {nor }, \text { amb }}+273 \cdot 15^{\circ} C}{\vartheta_{\text {amb }}+f_{\text {ref }} \cdot E_{D N I} \cdot C_{\text {cooler }}+273 \cdot 15^{\circ} C}(a) \\ \frac{\vartheta_{u p, \text { Stirling }}-\left(\vartheta_{\text {amb }}+f_{\text {ref }} \cdot E_{D N I} \cdot C_{\text {cooler }}\right)}{\vartheta_{u p, \text { Stirling }}-\vartheta_{\text {norm }, \text { amb }}}(b)\end{array}\right.$

(a) : reciprocal model

(b) : Carnot model

$\vartheta_{\text {norm,amb }}$ : normalized temperature for performance model in ${ }^{\circ} \mathrm{C}$

$\vartheta_{\text {amb }}$ : actual ambient temperatue in ${ }^{\circ} \mathrm{C}$

$\vartheta_{\text {up,Stirling }}$ : upper Stirling temperature in ${ }^{\circ} \mathrm{C}$

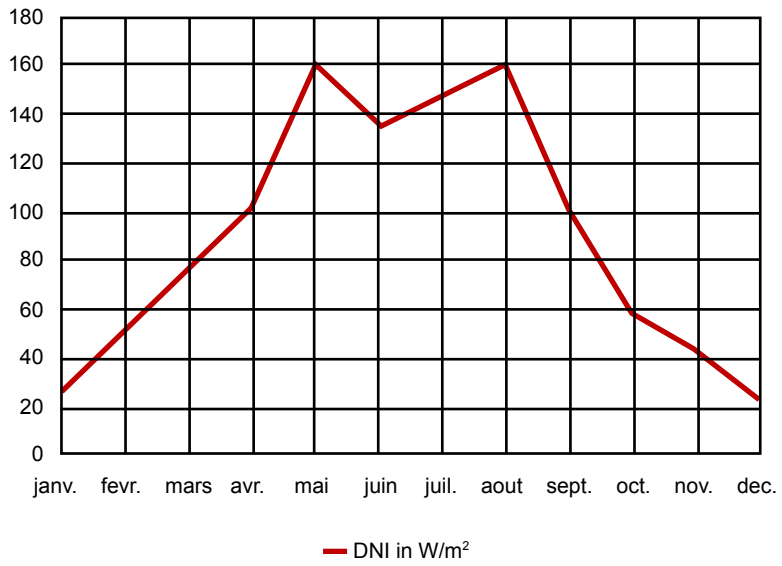

Figure 2: Monthly variation of the direct irradiance normal DNI according to the year.

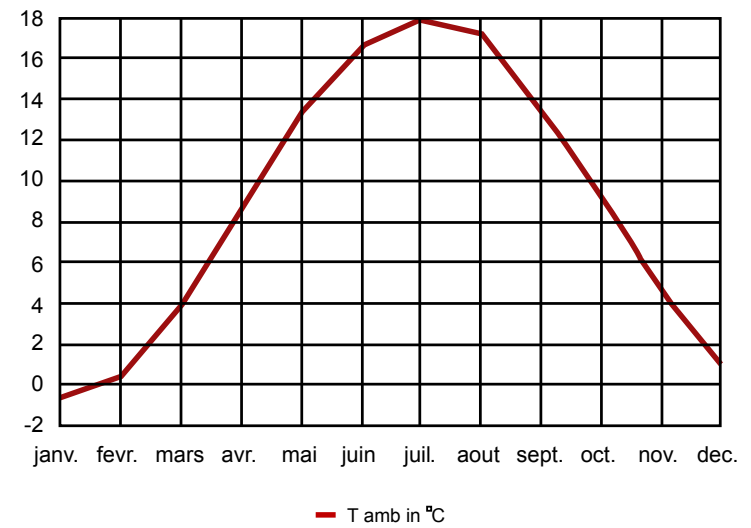

Figure 3: Monthly variation of the ambient temperature $T_{\text {amb }}$ according to the year.

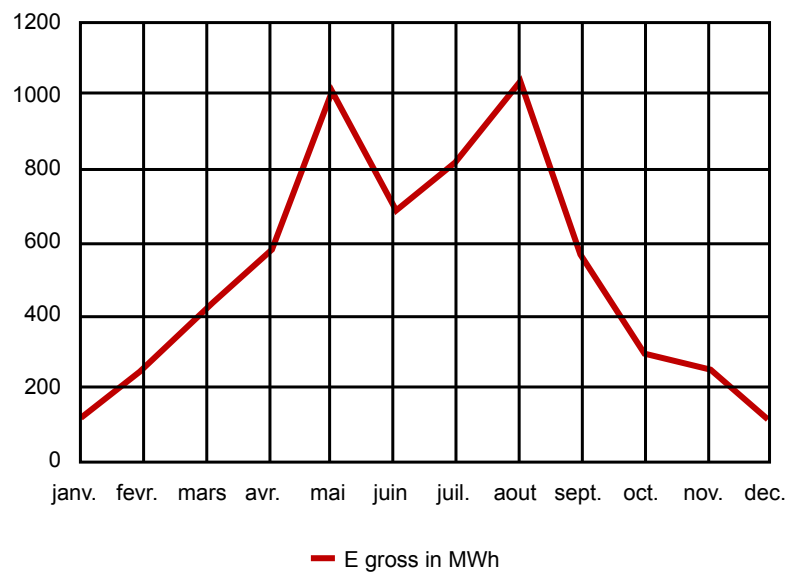

Figure 4: Monthly variation of the gross energy $\mathrm{E}_{\text {gross }}$ according to the year.

$\mathrm{C}_{\text {cooler }}$ : cooler constant in ${ }^{\circ} \mathrm{C} /\left(\mathrm{W} / \mathrm{m}^{2}\right)$

Parasitics:

$P_{\text {parasitic }}=\left\{\begin{array}{l}P_{\text {oper }}(1) \\ P_{\text {sleep }}(2)\end{array}\right.$

(1) for $\mathrm{E}_{\mathrm{DNI}} \geq \mathrm{E}_{\mathrm{DNI}, \min }$

(2) for $\mathrm{E}_{\mathrm{DNI}}<\mathrm{E}_{\mathrm{DNI}, \text { min }}$

Power to/from the grid:

$\mathrm{P}_{\text {grid }}$ : performance to/from the grid in $\mathrm{W}$

$\mathrm{P}_{\text {gross }}$ : gross performance in $\mathrm{W}$

$\mathrm{P}_{\text {parasitic }}$ : total parasitics in $\mathrm{W}$

\section{Simulation and Results}

All input parameters of Greenius are filled with practical parameters when creating a new project. The technology of Dish Stirling and a meteorological data file must be chosen. Then, all parameters can be changed and the simulation can be started at any time. This is done at the menu entry Project Case/Recalculate... respectively the key F9. The simulation is always done for a typical operation year with 8760 


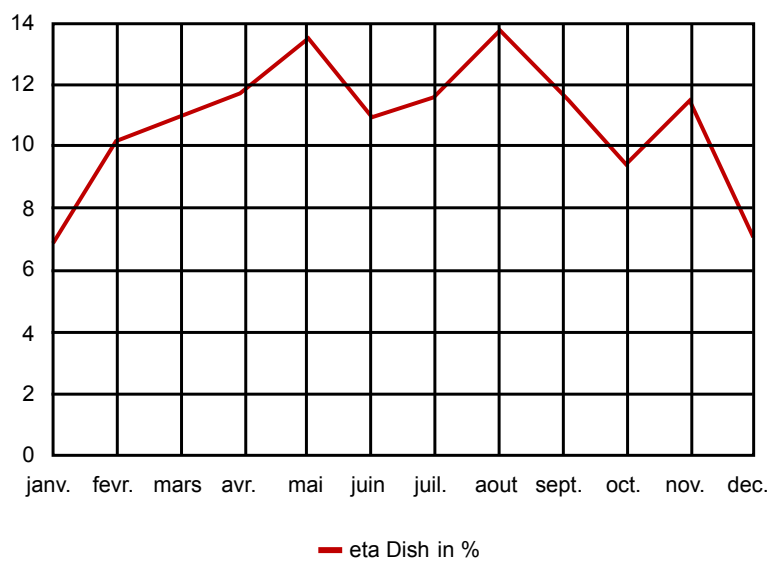

Figure 5: Monthly variation of the dish efficiency according to the year.

hourly values. The powerful algorithms of Greenius allow very fast simulations that can also be stopped manually. In figures 2, 4 and 5, the direct irradiance normal DNI, the gross energy $\mathrm{E}_{\text {gross }}$ and the dish efficiency start with the values relatively weak $26.3^{\text {gross }} \mathrm{W} / \mathrm{m}^{2}, 120.06$ MWh and $6.52 \%$ respectively in January, and they increase up to the two maximum values in May and August: $\mathrm{DNI}=(158.1-160.1) \mathrm{W} / \mathrm{m}^{2}$, $\mathrm{E}_{\text {gross }}=(988.81-1043.17) \mathrm{MWh}$ and dish efficiency $=(13.76-14.15) \%$. After they decrease gradually up to $21 \mathrm{~W} / \mathrm{m}^{2}, 105.24 \mathrm{MWh}$ and $6.59 \%$ respectively in December.

In figure 3, the ambient temperature starts with the lower value $-0.5^{\circ} \mathrm{C}$ in January, then it increase up to the maximum value $17.9^{\circ} \mathrm{C}$ in July. It decreases gradually up to $1.1^{\circ} \mathrm{C}$ in December.

\section{Conclusion}

All algorithms of Greenius has been implemented and tested carefully. However, calculation errors or uncertainties of the used models can never be avoided totally. Furthermore, incorrect bad chosen input parameters can produce results with high deviations from the reality. It is, therefore, strictly recommended that specialists verify all simulation results. No liability is accepted for any claims due to wrong simulation results. In order to enable a complete simulation including investment cost and LEC calculation equipment costs are implemented for all technologies [10].

Industrial side, the American company Stirling Energy Systems beat the record of effectiveness in conversion solar-electricity on January 31,2008 , reaching $31.25 \%$. The preceding record, going back to 1984 was $29.4 \%$. This system is particularly interesting in zones where the solar electricity is mainly made up of direct radiation, i.e. in inter tropical zones. The companies in the course of launching of production of this system announce launching into 2009 of complete installations with converter of electricity, which should be able to compete with the photovoltaic panels [11].

\section{References}

1. Quaschning V (2006) Regenerative Energiesysteme. Hanser Verlag München, Auflage.

2. Schulte-Fischedick J, Tamme R, Herrmann U (2008) CFD Analysis of the Cool Down Behaviour of Molten Salt Thermal Storage Systems. Proceedings of the ES2008, Energy Sustainability 2008, August 10-14, 2008, Jacksonville, Florida.

3. Stirling Engines G, Walker (1980) Clarenden Press. Oxford.
4. Rochelle P (2005) LTD Stirling engine simulation and optimization using finite dimension thermodynamic. In: Proceedings of the $12^{\text {th }}$ international Stirling engine conference, Durham University, UK.

5. Kongtragool B, Wongwises S (2006) Thermodynamic analysis of a Stirling engine including dead volumes of hot space, cold space and regenerator. Renew Energy 31: 345-359.

6. Senft JR (1991) An ultra low-temperature differential Stirling engine. In Proceeding of the $5^{\text {th }}$ international Stirling engine Conference, paper ISEC 91032, Dubrovnik.

7. Organ AJ (1997) The regenerator and the Stirling engine. Mechanical Engineering Publications, London.

8. Van Arsdell BH (2001) Stirling engines. In: Zumerchick J (Eds.) Macmillan encyclopedia of energy 3: 1090-1095.

9. Theunissen PH, Beckman WA (1985) Solar transmittance characteristics of evacuated tubular collectors with diffuse back reflectors. Solar Energy 35: 311 320.

10. Amara S, Nordell B, Benyoucef B, Benmoussat B (2011) Concentration heating system with optical fiber supply. Energy Procedia 6: 805-814.

11. Kaddour A, Benyoucef B (2011) Simulation of a photo-solar generator for an optimal output by a parabolic photovoltaic concentrator of Stirling engine type. Phys Procedia 21: 140-145. 